af renæssancens og det tidlige moder- og Efterladte fortallinger er store dele af nes politiske tænkning. Med fokus på Kafkas forfatterskab blevet lettere tiltænkere som Machiavelli og Hobbes gængeligt for danske læsere. Værket, en har Skinner undersøgt og rekonstru- tiltrængt og flot udgivelse, fremstår som eret denne periodes politiske tænkning en ny standardudgave af Kafkas fortæli bredden og fundet nye og spændende linger på dansk - og er derfor et must forbindelseslinjer som mere traditionel for alle litteraturelskere, Kafka-fans og filosofi- og idéhistorisk litteratur på om- folk med hang til at samle på store klasrådet har overset. I denne sammenhæng sikere. Fortallinger rummer alle de tekster har den danske tekstsamling medtaget som Kafka selv offentliggjorde i sin en række eksemplariske artikler. levetid; Efterladte fortallinger indeholder

Tekstsamlingen er vel oversat, har alle større fortællinger og fragmenter som sagt en fremragende indføring af (parabler, aforismer, dagbogsoptegnelFrank Beck Lassen og Mikkel Thorup ser og selvbiografiske skitser) fra hans og der er på denne baggrund absolut efterladte papirer. Redaktionelt har man ingen undskyldninger for ikke at stifte valgt at lade Villy Sørensens og Per Øhrbekendtskab med Skinners tilgang til gaards gamle oversættelser fra Dommen den idéhistoriske metier. Bogen bør og andre fortallinger fra 1967 indgå i revivære pligtlæsning for alle med interesse deret form i denne udgave. Fornuftigt for det idéhistoriske felt, og for manges nok; de udgør i sig selv et lille sprogligt vedkommende er jeg sikker på, at pligt- og litterært mesterværk.

læsningen vil forvandle sig til lystlæs- De resterende fortællinger, som ning, så snart de får øjnene op for det udgør langt størstedelen af materialet, store idéhistoriske anvendelsespoten- er oversat af Isak Winkel Holm. Jeg tiale, der findes i Skinners rekonstruk- synes godt om denne oversættelse. Det tion af fortidige teksters betydning i siger næsten sig selv, at det er alt andet samspil med deres sproglige kontekst. end nemt at oversætte Kafkas på mange måder ellers meget stringente og klare, men alligevel fuldstændig surrealistiske prosa. Det er nærliggende enten at forfalde til ironisk distance eller til en

RIKKE LOUISE PETERS

\section{Kafka på dansk}

Franz Kafka: Fortallinger 1 \& 2, Gyldendal, 2008, $267+419$ sider, 450,-kr.

Med Gyldendals nye store Kafka-sats- stil. Stilen er gammeldags uden at virke ning bestående af to bind: Fortallinger bedaget. 
Der er et fortolkende element i offentliggjorde. Kafka-kendere ved, at enhver oversættelse, ligesom det er en han kun offentliggjorde en brøkdel af klassisk hermeneutisk pointe, at ingen sine litterære tekster. Ved sin død efteroversættelse er den endelige - ja det er lod han sig godt 3.000 sider uafsluttet ligefrem det primære kendetegn for en materiale, som han i et berømt brev til klassiker, at den kan (og bliver) genover- sin bedste ven, Max Brod, bad om måtte sat med jævne mellemrum. Noget af det blive brændt. En beslutning Max Brod samme gør sig gældende, når det kom- (heldigvis) valgte at trodse. Fortællingen mer til redaktionelle valg og principper; 'En sultekunstner' iscenesætter det for de er båret af redaktørens fortolkning udenforstående yderst bizarre fænoog vurdering af teksten og ændrer sig men sultekunst/spisevægring. En på alle med tiden. Kafka-forskere og filolo- måder paradoksal, meningsløs og irreal ger kan sikkert komme med adskillige tilstand, hvor kroppen taler gennem sin indvendinger mod de valg og skøn, der egen udslettelse - men som indefra beer truffet her, men de vil næppe ændre tragtet er en helt reel tilstand og derfor noget ved det overordnede indtryk, meningsfuld og nødvendig, fordi det hvorom der kan siges: det virker. Det er netop er den eneste måde at kommuniflot udført og af varig kvalitet. Kere på, når andre kommunikationsmu-

Kafkas forfatterskab er først og ligheder er udtømte. Man kunne kierkefremmest interessant for filosoffer og gaardsk formulere det sådan, at sulteidehistorikere, fordi det udgør en helt kunstnerens indre er inkommensurabelt eminent kilde til modernitetens grund- med den ydre verden. Som det hedder læggende temaer og problemstillinger, et sted i fortællingen: "Prøv at forklare som vi stadig tumler med og som måske nogen sultekunsten! Den der ikke føler endda er blevet skærpet i det senmo- det, ham kan man heller ikke gøre det derne. Fortællingerne udgør et katalog begribeligt.” (s. 216) Det fantastiske over diverse fremmedgørelses- og hjem- ved denne fortælling er selvfølgelig, at løshedsmetaforer, såvel som absurdi- Kafka både skildrer sultekunsten som tets- og angstproblematikker til hobe. et kulturhistorisk fænomen og samtidig Tematisk er fortællingerne spændt ud som en eksistentiel, indre tilstand, og at i dikotomien mellem det indre og det de to niveauer i fortællingens flydende ydre; mellem individet og omverdenen, prosa går op i en højere enhed uden at psyken og kroppen, kroppen og den dikotomien ophæves.

anden, moralen og loven, psyken og Kafkas forfatterskab handler altså sproget. Måske tydeligst i den mesterlige om helt klassiske filosofiske problemstilfortælling 'En sultekunstner' fra 1922, linger, som dukker op i moderniteten skrevet to år inden Kafka døde i 1924 første gang hos Hegel og romantikerne. og en af de fortællinger han rent faktisk Det drejer sig om friheds- og anerken- 
delsesproblematikken, om skyldbegre- publikums anerkendelse. Til slut dør sulbet samt om det, man kunne kalde viljen tekunstneren, og to stærke opsynsmænd til at lykkes. Det moderne individ vil ses, bærer ham ud af buret og erstatter ham mødes og anerkendes som individ af med en altædende ung panter. Så kan andre individer i forskellige sociale eller der til slut i fortællingen gøres kort profamiliære relationer, $\mathrm{fx}$ i forholdet til den ces: "Panteren manglede intet. Den føde nære familie, vennen, den elskede, job- den kunne lide, kom dyrepasserne med bet, myndighederne eller massen/publi- uden at gøre sig mange tanker om det; kummet. Her kommer det abstrakte fri- ikke engang friheden syntes den at savne hedsbegreb til kort, for nok kan vi være [...]" (s. 217).

frie konstitutionelt eller filosofisk set, Med Fortallinger 1 \& 2 er der nu en men deraf følger ingenlunde, at vi er frie oplagt mulighed for at stifte bekendti mødet med det andet menneske. Frihe- skab med sultekunstneren, Josephine, den bunder nemlig i noget dybere, i den Den lille Kvinde, Gregor Samsa, Georg indre frihedsfølelse, som imidlertid - og Bendemann, Josef $\mathrm{K}$ og de mange tragisk nok kunne man tilføje - stadig er andre personer i forfatterskabet. Der er dialektisk i sin form, fordi den er afhæn- kun ét at sige: Ta' og læs!

gig af de andres anerkendelse af én som individ.

Som Hegel havde blik for og som Sloterdijk sidenhen har taget op, er anerkendelsen dialektisk forbundet med kampen og modstanden og ikke mindst med foragten, og det er i denne tragiske dialektik, Kafkas personer bliver fanget. Deres søgen er rettet mod en absolut anerkendelse, som bliver tragisk, idet den er umulig, og derfor slår om i en absolut skyld eller absolut negligering. Der gives ingen mellemvej eller mulighed for forsoning mellem individ og omverden. Sultekunstnerens søgen er, i modsætning til publikums hang til sensation, en eksistentiel og i bund og grund metafysisk søgen efter, som han siger det: "den spise som jeg kan lide." (s. 217), dvs. efter mening. Men forsoningen kommer ikke i stand, for han opnår aldrig sit 